\title{
Effect of Illegally Refined Crude oil ("kpo-fire") Residue on Soil Fungi
}

\author{
Douglas, Salome Ibietela* \\ Department of Microbiology, Faculty of Science, Rivers State University, Nkpolu- \\ Oroworukwo, PMB 5080, Port Harcourt, Rivers State, Nigeria \\ *Corresponding author
}

\section{Keywords}

Illegal refining, "kpo-fire" residue, Soil fungi, Toxicant, Crude oil

\section{Article Info}

Accepted:

24 October 2018

Available Online:

10 December 2018

\section{A B S T R A C T}

Soil pollution by crude oil and its by products as a result of illegal ("Kpo-fire") crude oil refining is one of the most common environmental challenges in the Niger Delta. This study was carried out on a laboratory scale, to evaluate the effect of illegally refined crude oil residue on soil fungi, using standard microbiological methods. Soil samples were taken from the University farm where there is no history of such contamination. The illegally refined crude oil residue (kpo-fire residue) used in this study was obtained from an illegal(artisanal) crude oil refining site in Boodo community, Gokana Local Government Area of Rivers State. The soil samples were then contaminated with various concentrations $(0 \%, 25 \%, 50 \%$ and $75 \%)$ of the "Kpo-fire" residue; this was monitored every seven days, for 28days. Total heterotrophic and hydrocarbon utilizing fungal counts were investigated in the soils with varying concentrations of the illegal crude oil residue added. The mean total heterotrophic fungal counts ranged from $2.4 \times 10 \mathrm{cfu} / \mathrm{g}$ to $6.7 \times 10^{4} \mathrm{cfu} / \mathrm{g}$, while the mean hydrocarbon utilizing fungal counts ranged from $1.6 \times 10 \mathrm{cfu} / \mathrm{g}$ to $3.4 \times 10^{3} \mathrm{cfu} / \mathrm{g}$. The following fungi were isolated and identified in the day 1 from the samples; Aspergillus niger, Aspergillus flavus, Penicillium species, Rhizopus sp, Fusarium solani, Mucor sp, Candida sp, Cladosporium sp and Saccharomyce species. While on day 28, only four; Aspergillus niger, Aspergillus flavus, Mucor and Rhizopus sp out of the nine isolates were identified. It was observed that the higher the concentration of the residue, the more the effect on the fungal population and diversity. The decrease in species composition and the fungal populations observed are indicative of the effect of the illegally refined crude oil residue on the soil fungal population and diversity. The continual dumping of this residue into the soil environment, will in turn affect the ecological balance, since these organisms play very important role in the ecosystem.

\section{Introduction}

Since 1958, that Nigeria got involved in the large scale exploration of crude oil; which has continuously grown and become the main stay of the nation's economy. This has resulted in diverse environmental pollution problems in the Niger Delta region (Okpokwasili et al.,
2013). Before now, the pollution problems were due to oil spills as a result of accidents and equipment failure, but in recent times it's as a result of man's activities such as vandalism, oil bunkering (Okpokwasili et al., 2013) and these days majorly form illegal refining of crude oil. Most youths have found it to be a very lucrative venture, to set up these 
illegal refineries, and it is estimated that between 70,000 and 300,000 barrels of crude oil are stolen daily, most of which are sold and about 25\% are refined locally (Onuoha, 2013 and SDN, 2013). "kpo-fire" is a local slang used to describe the artisanal refinery process, which is coined from the explosive sound heard when oil is used as the fuel for the refining purpose (UNEP, 2011). It is a simple fractional distillation process, using locally sourced materials. Some of the materials used includes; metal pipes and drums welded together in which crude oil is boiled and the resultant fumes are collected in tanks after they are cooled, condensed and the resultant products which includes kerosene, diesel and fuel (PMS) which are used locally for lighting, energy or transport (UNEP, 2011). Refining of the crude oil by this method, yields $2 \%$ kerosene, $2 \%$ fuel, $41 \%$ diesel and $55 \%$ waste (SDN, 2013). After the products of interest are collected, large quantities of residue (waste) are produced, which are being dumped indiscriminately on land, in the nearest water body causing environmental pollution. Part of the residue is also used as fuel for further refining process.

Crude oil is a complex heterogenous liquid composted of many hundreds of hydrocarbon, which according to UNEP 2006, reported that, the impact of pollution in the Niger Delta is gradually moving to a catastrophic end, causing the physiochemical properties of the soil to change greatly, resulting in the depletion of biodiversity in the soil environment.

There are billions to hundreds of billions of soil microorganisms in a one gram of a typical garden soil. That a single handful might contain thousands of different species of bacteria, hundreds of different species of fungi and protozoa, dozens of different species of nematodes plus a goodly assortment of various mites and other micro arthropods (Kolwzan et al., 2006). Most of these countless soil microorganisms are not only beneficial but also essential to the life giving properties of the soil. Fungi are eukaryotic, heterotrophic, aerobic, non-chlorophyll containing organisms, which use carbon and energy to build their own cell from decomposition of organic matter (Kolwzan et al., 2006). They are mostly found in the upper layers of soil and are involved in symbiotic relationship with other organisms like algae, insects and plants. The soil fungi break down and then convert organic materials into plant nutrients, holding these nutrients in place and make them available to the plants (Kolwzan et al., 2006).

Play a great role in soil structure as they create humus, which influences its structure, sorption qualities and richness in organic compounds. In plant nutrition, these microorganisms play a role in the physiology of the plants. Some common soil fungi are the genera of: Penicillium, Aspergillus, Cladosporium, Trichoderma, Verticillium, Fusarium, Rhizopus, Mucor, Zygorhynchus, Chaetomium (Kolwzan et al., 2006). When these residues (deposits) are dumped in the soil, it may affect many microbial processes that go on in the soil environment including nutrient recycling, degradation and decomposition of plants and animals tissues, bioremediation, humus formation etc which depends on the equilibrium among the various groups of soil microorganisms (Rangaswami, 2004; Douglas and Nwachukwu, 2016). This therefore, informs this study to evaluate the effect of illegally refined crude oil residue on soil fungal population.

\section{Materials and Methods}

\section{Collection of the crude oil deposit}

The illegally refined crude oil residue used for this study was obtained from an illegal crude 
oil refining site in Boodo community, in Gokana Local Government Area of Rivers State.

\section{Collection of soil sample}

The soil samples used for this study were collected from the school farm, where there is no previous history of oil pollution. Samples were collected at three different points, using soil auger at a depth of about $15 \mathrm{~cm}$ deep and about $1 \mathrm{~m}$ apart. These samples were pulled together for homogeneity, in sterile plastic bags and taken to the Laboratory. In the laboratory, $500 \mathrm{~g}$ of the samples were weighed and put in sterile clay pots, labeled A to D, in duplicates.

The concentrations of the "kpo-fire" deposit used include: $75 \%, 50 \%, 25 \%$, and $0 \%$ respectively, were put in the plates and mixed thoroughly using hand trowel (Ibiene et al., 2011). Plate D is the control with zero oil (Table 1). This experimental setup was allowed to stand for 28 days and monitoring was done on days: 1, 7, 14, 21 and 28. This setup was watered with sterile distilled water and tilled once a week to provide moisture and oxygen for the organisms (Obire and Anyanwu, 2009).

\section{Total heterotrophic fungal counts}

The spread plate method was used for the enumeration of the total heterotrophic fungal counts. One gram (1g) of soil sample was taken from each pot and aseptically transferred into $9 \mathrm{ml}$ of sterile normal saline. This was serially diluted to $10^{-4}$, the same procedure was followed for all samples. Using a sterile pipette, $0.1 \mathrm{ml}$ aliquot was dropped into the surface of already prepared sterile Sabouraud dextrose agar plate, supplemented with $0.5 \mathrm{~g} / 1$ of chloramphenicol in duplicates. Using sterile hockey stick the inoculum was evenly spread in duplicates; plates were incubated at $28^{\circ} \mathrm{C}$ for 5 to 7days. Thereafter, counts were taken to calculate the colony forming unit and colonies that developed were further purified by subculturing using the SDA. Pure isolates were stored at $4^{0} \mathrm{C}$ on SDA slants until required for further analysis (Douglas and Amuzie, 2017).

\section{Hydrocarbon utilizing fungal counts}

The vapour phase transfer method using Mineral salt medium composition of Mills et al., 1978 was used as modified by Okpokwasili and Okorie, 1988. This media was also supplemented with $0.5 \mathrm{~g} / 1$ of chloramphenicol. Plates were incubated at $28^{\circ} \mathrm{C}$ for 5 to 10 days. Colonies that developed were counted and sub cultured to get pure isolates, which were stored on SDA slant for further use.

\section{Microscopic and morphological characterization of fungal isolates}

Characterization and identification of the fungal isolates were done both macroscopically and microscopically (Barnett and Hunter, 1972; Cheesbrough, 2000). Macroscopic examination of mould growth was done by observing the colonial morphology. Colour of colony, shape and surface appearance. Using the wet mount method as described by Cheesebrough, 2000 from plates of pure culture a portion of the isolate is carefully teased removed and placed on a clean slide. Two drops of lactophenol were added to the smear and covered with a cover slip and examined under the X10 and $\mathrm{X} 40$ of the microscope. The organisms were identified based on their mycelial structure and fruiting body.

\section{Results and Discussion}

This study focused on the impact of hydrocarbon pollution emanating from 
artisanal refining on soil fungi. The total heterotrophic fungal mean counts ranged from $2.4 \times 10 \mathrm{cfu} / \mathrm{g}$ to $6.7 \times 10^{4} \mathrm{cfu} / \mathrm{g}$, while the hydrocarbon utilizing fungal mean counts ranged from $1.6 \times 10 \mathrm{cfu} / \mathrm{g}$ to $3.4 \times 10^{3} \mathrm{cfu} / \mathrm{g}$. Figure 1 shows the results of the total heterotrophic fungal counts. Initially, a reduction in fungal population was observed on day 7 for all concentrations except for the control. Thereafter, there was an increase in day 14 and 21, by day 28 there was a decrease again. For $50 \%$ concentration, there was also a decrease on day 7 with increase in day 14, thereafter there was a decrease until day 28 . Also, for the $75 \%$ concentration a decrease was observed for day 7 to 14 , a slight increase was observed for day 21 and a decrease until day 28. The higher total heterotrophic fungal counts observed in the unpopulated soil (control) was also observed by Obire and Anyanwu, 2009; Douglas and Green, 2015. This may be attributed to the toxic effect of the deposit on some species, which may have been killed or inhibited. Figure 2 shows the results of hydrocarbon utilizing fungal counts, higher counts were observed in the polluted set ups than the unpolluted control. There was no much change in fungal counts over time in the control.

While for the polluted soil samples, a drop in fungal population on day 7 was observed, after which there was an increase in population of the hydrocarbon utilizing fungi. This was observed until day 28 when there was a decrease again in the fungal population. Higher hydrocarbon utilizing fungal counts in the polluted soil may be due to the stimulatory effect of deposit which served as nutrients to these organisms. The following fungi were isolated and identified in the day 1 (Table 2); Aspergillus niger, Aspergillus flavus, Penicillium species, Rhizopus sp, Fusarium solani, Mucor sp, Candida sp, Cladosporium $\mathrm{sp}$ and Saccharomyce species. While on the day 28, only four (Aspergillus niger,
Aspergillus flavus, Mucor and Rhizopus sp) of the eight isolates were isolated. In a previous study by Obire and Anyanwu (2009), where soil samples were contaminated with crude oil. a total of fourteen isolates were identified which include: Alternaria sp.; Aspergillus sp.; Cephalosporium sp.; Cladosporium sp.; Fusarium sp.; Geotrichum sp.; Mucor sp.; Penicillium sp.; Rhizopus sp. Trichoderma sp. Candida sp.; Rhodotolura sp.; Saccharomyces sp. and Torulopsis sp were isolated from the control while five hydrocarbon utilizing fungal were identified out of the fourteen. But in this study, the following were not identified; Alternaria sp, Cephalosporium sp.; Geotrichium sp.; Rhodotolura sp.; Trichoderma sp. Also, from another research of Douglas and Green, 2015, eight isolates were identified, except Geotrichum sp. which was not isolated from this study. In another related work by Douglas and Nwachukwu, 2016, only six fungal isolates were identified from the soil sample. A decrease in fungal diversity was also observed with increase in concentration of the residue; the control had the highest diversity while the $75 \%$ illegal crude oil toxicant concentration had the least diversity.

The introduction of the residue into the soil resulted in a selective increase and decrease in population and diversity of fungal in the soil. The decreasing diversity with increase in concentration may be attributed to the environmental stress as a result of the added illegal crude oil deposit (Obire and Anyanwu, 2009). It was also observed that, when the crude oil residue was applied as a source of carbon and energy through the process of vapour phase transfer method, on Petri dishes, no growth was seen. This means that the residue did not support microbial growth. This may be due to the fact that the volatile components have been used up during the fractional distillation process leaving behind the heavier fractions (or less-volatile). 

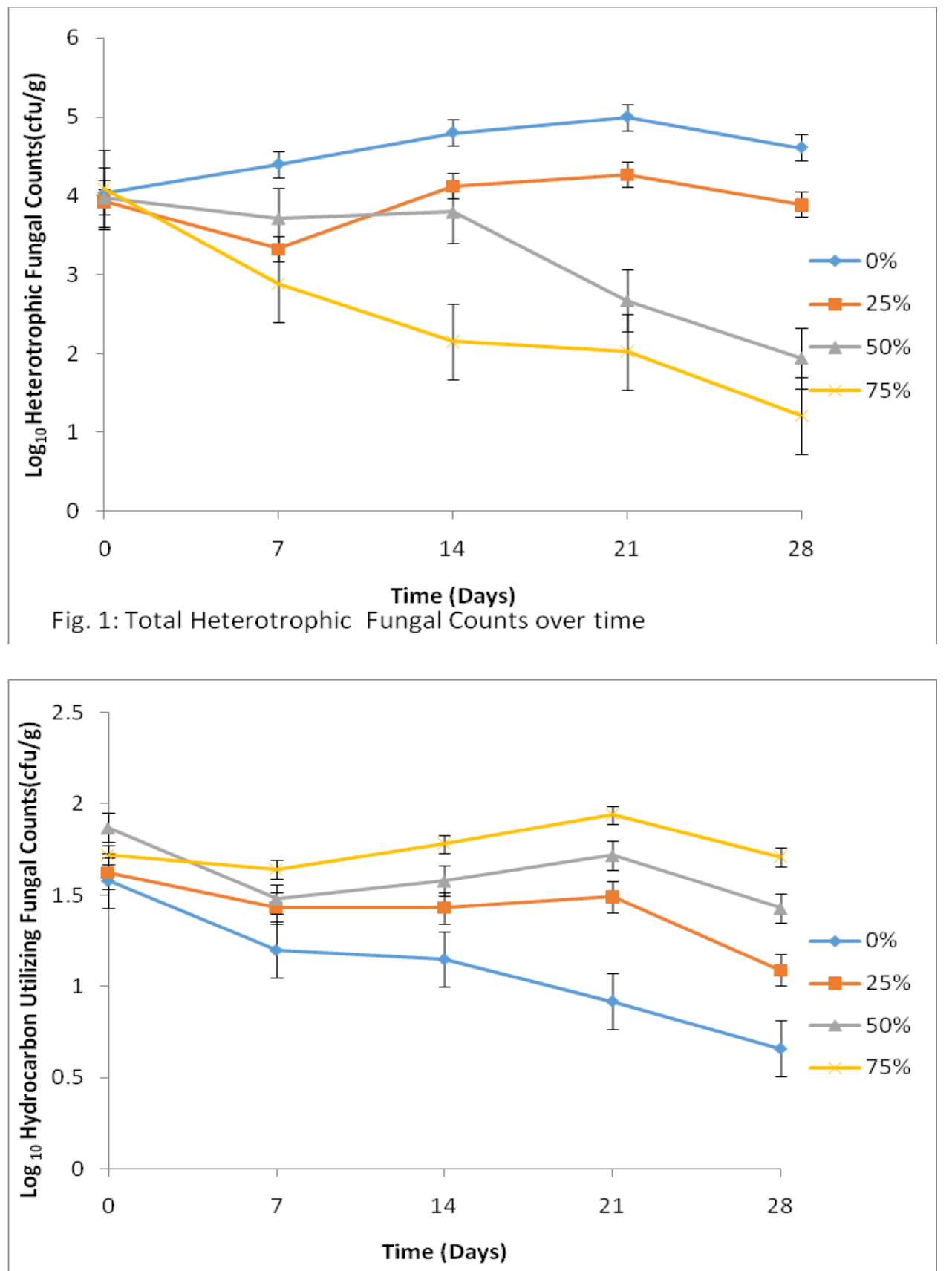

Fig. 2 : Hydrocarbon Utilizing Fungal Counts over Time

Table.1 Experimental setup

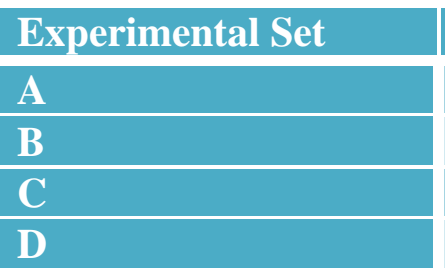

Constituents

$500 \mathrm{~g}$ of soil $+75 \mathrm{mls}$ of the residue

$500 \mathrm{~g}$ of soil $+50 \mathrm{ml}$ of the residue

$500 \mathrm{~g}$ of soil $+25 \mathrm{ml}$ of the residue

$500 \mathrm{~g}$ of soil no residue was added (served as control) 
Table.2 Macroscopic and microscopic characteristics of the fungal isolates

\begin{tabular}{|c|c|c|c|}
\hline Lab code & Colonial Morphology & Microscopic Characteristics & Probable Identity \\
\hline MS1 & $\begin{array}{l}\text { Creamish spots, later turns dark } \\
\text { brown to black }\end{array}$ & $\begin{array}{l}\text { Septate } \\
\text { conidiophores } \\
\text { containing conidia }\end{array}$ & Aspergillus niger \\
\hline$\overline{\text { MS2 }}$ & $\begin{array}{l}\text { Creamish colonies that changes } \\
\text { to dark brown }\end{array}$ & $\begin{array}{l}\text { Septate hyphae with unbranched } \\
\text { conidiophores }\end{array}$ & Aspergillus flavus \\
\hline TF1 & $\begin{array}{l}\text { Whitish spots at the initial } \\
\text { growth, but later changes to } \\
\text { greenish powdery surface }\end{array}$ & $\begin{array}{l}\text { Septate hyphae with branched } \\
\text { conidiophores }\end{array}$ & Penicillum sp \\
\hline TF2 & $\begin{array}{l}\text { Wooly whitish colony that turns } \\
\text { dark later }\end{array}$ & $\begin{array}{l}\text { Non-septate hyphae branched } \\
\text { sporangiophores, bearing round } \\
\text { sporangia }\end{array}$ & Rhiz \\
\hline TF3 & $\begin{array}{l}\text { Whitish cottony lawn like } \\
\text { growth. The reverse } \\
\text { yellowish }\end{array}$ & $\begin{array}{l}\text { Septate hyphae, with banana } \\
\text { shaped septate conidia }\end{array}$ & Fusarium sp \\
\hline MS3 & $\begin{array}{l}\text { Fluffy whitish cottony growth. } \\
\text { Whitish on reverse side }\end{array}$ & $\begin{array}{l}\text { Nonseptate hyphae with } \\
\text { nonseptate sporangiophores }\end{array}$ & Mucor sp \\
\hline MS4 & $\begin{array}{l}\text { Creamish smooth round shiny } \\
\text { colonies }\end{array}$ & Spherical cells & Candida sp \\
\hline MS5 & $\begin{array}{l}\text { Radially furrowed dark brown } \\
\text { velvety growth with white } \\
\text { periphery }\end{array}$ & $\begin{array}{l}\text { Produce conidia in branched } \\
\text { chains }\end{array}$ & Cladosporium sp \\
\hline TF4 & $\begin{array}{l}\text { Creamish, raised, shiny, } \\
\text { spherical colonies }\end{array}$ & $\begin{array}{l}\text { Spherical or oval large budding } \\
\text { cells }\end{array}$ & Saccharomyces sp \\
\hline
\end{tabular}

From the results of this research work, it was observed that this illegally refined crude oil deposit contamination of the soil affected the fungal population and diversity drastically. Soil fungi, like other soil organisms play very important role in the soil ecosystem; especially their interactions with other organisms in the food chain. Most soil fungi are saprophytes, which helps them in the decomposition and nutrient recycling, they help in converting complex substances into simpler forms and this ensures continuous soil fertility (Barnett, 1998). They have the ability to quickly colonize substrates due to their morphology and growth properties. They can produce extracellular enzymes which enables them assimilate complex organic compounds with prior hydrolysis which makes it possible for degradation of a great number of pollutants (Leitab, 2009). Some species may also be pathogenic to plants. They have also been shown to produce various metabolites and bioactive compounds used for various industrial purposes (Petit et al., 2009). Penicillium species are common inhabitants of the soil ecosystem and more than 200 species have been identified (Petit et al., 2009). Fusarium species were also eliminated by the introduction of this residue. Fusarium sp are also normal soil inhabitants of the soil environment, and could be associated with plants which could be saprophytes or endophytes (Sumerell et al., 2011). These organisms have the ability to degrade lignin and other complex carbohydrates found in soil organic debris. As endophytes they colonise the cortex and xylem of plant roots and protects plants against other pathogens or may even suppress plant disease. They produce diverse secondary metabolites like: 
antibacterial, antifungal and many more (Sumerell et al., 2011). Yeast population was also affected by the residue. These organisms play key role in microbial and plant growth, soli aggregate formation and maintenance of soil structure, nutrient recycling (especially $\mathrm{N}$ and $\mathrm{P}$ ), mineralization and decomposition. They are also sources of food for bacteria, protists, nematodes and arthropods (Botha, 2011). Seeing the various important role played by the various fungi genera, If this residue are continuously released into our environments it will in turn affect the ecological balance. Therefore, those involved in the business of illegal refining should be stopped by all means.

The results of this research has shown that increase in concentration of the illegally refined crude oil deposits in the soil resulted in a general decrease in species diversity and population of the fungal population over time. Therefore, with the continuous dumping of this deposit into the terrestrial environment, would affect the vital role played by this group of organisms in decomposition and interfere with other metabolic activities of the organisms in the soil environment.

\section{References}

Barnett, H. L., and Hunter, B. B. (1972) Illustrated Genera of Fungi Imperfecti, 3rd edition, Burgess Publication Co Minneapolis.

Botha, A. (2011) Importance and Ecology of Yeast in soil. Soil Biology and Biochemistry 43(1): $1-8$.

Cheesebrough, M. (2000) District Laboratory Practice in Tropical Countries. Part 2, Cambridge University Press, London, UK. Pp 143 - 156.

Douglas, S. I. and Green, D. I. (2015) Microbial Communities Found in Diesel Contaminated Soil. International
Journal of Physical \& Applied Sciences. 2(4): $38-48$.

Douglas, S. I. and Nwachukwu, E. U. (2016) Effect of Spent Battery Waste on Soil Microorganisms. International Journal of Current Microbiology and Applied Sciences. 5(11): 867 - 876

Douglas, Salome Ibietela and Amuzie, C. C. (2017) Microbiological Quality of Hoplobatrachus occipitalis (Amphibia, Anura) Used as Meat. International Journal of Current Microbiology \& Applied Sciences. 6(6): 3192 - 3200.

Ibiene, A. A., Orji, F. A., Ezidi, C. O. and Ngwobiai, C. L. (2011) Bioremediation of Hydrocarbon contaminated Soil in the Niger Delta Using Spent Mushroom Compost and other Organic Waste. Nigerian Journal of Agriculture, Food \& Environment. 7(3): 1-7.

Kolwzan, B., Adamiak, W., Grabes, K. and Pawelczyk, A, (2006) Introduction to Environmental Microbiology. Oficyna Wydawnicza Politecniki Wroclawskiej, Wroclaw, Poland. Pp 11 to 16

Leitab, A. L. (2009) Potential of Penicillium species in the Bioremediation Field. International Research of Environmental and Public Health. 6: 1393 - 1417.

Mills, A. L., Breuil, C., and Colwell, R. R. (1978). Enumeration of Petroleumdegrading marine and estuarine microorganisms by the most probable number. Canadian Journal of microbiology. 24(5): 552 - 557

Obire, O. and Anyanwu, E. C. (2009) Impact of various concentrations of Crude oil on Fungal Populations of Soil. International Journal of Environmental Science Technology. 6(2): 211 - 218.

Okpokwasili G.C., Douglas S.I. and Inengite A.K. (2013) Seasonal variations of some physicochemical parameters of groundwater in crude oil flow stations. 
Journal of Environmental Science and Water Resources. 2(1): 016 - 021.

Okpokwasili, G. C. and Okorie, B. B. (1988)

Biodeterioration potentials of

Microorganisms isolated from car engine lubricating oil. Tribol Int. 21(4); $215-220$.

Onuoha, F. C. (2013) Oil Resources Management and Illegal Oil Bunkering in the Niger Delta Nigeria, 1999- 2011. A Ph.D, Thesis submitted to the Department of Political Science University of Nigeria, Nsukka.

Petit, P., Lucas, E. M. F., Abreu, L. M., Pfenning, L. H. and Takahashi, J. A. (2009) Novel antimicrobial secondary metabolites from a Penicillium sp isolated from Brazillian Cerrado soil. Electronic Journal of Biotechnology 12(4): $1-7$.
Rangaswami, G. (2004) Agriculture Microbiology. Prentice Hall of India.

SDN (2013) Communities not Criminals; Illegal Oil Refining in the Niger Delta. London, United Kingdom. $16-18$. www.stakeholderdemocracy.org

Sumerell, B. A., Leslie, J. F. Liew, E. C. Y., Laurence, M. H., Bullocks, Petrovic, T., Bentley, A. R., Howard, C. G., Peterson, S. A. Walsh, J. L. and Burgess, L. W. (2011) Fusarium species Associated with plants in Australia. Fungal diversity. 46: 1 - 27

UNEP, (2006) Ogoni Environmental Survey Project. United Nations Environmental Project Report. Accessed October, 2015. www.unep.org

United Nations Environmental Programme (UNEP, (2011). UNEP Report on Ogoni Land Nairobi, Kenya, Pp. 55 - 60.

\section{How to cite this article:}

Douglas, Salome Ibietela. 2018. Effect of Illegally Refined Crude oil ("kpo-fire") Residue on Soil Fungi. Int.J.Curr.Microbiol.App.Sci. 7(12): 3309-3316. doi: https://doi.org/10.20546/ijcmas.2018.712.382 